\title{
A new species of Potamocoris (Heteroptera: Potamocoridae) from Belize, and synonymy of the genus Coleopterocoris
}

\author{
Dan A. Polhemus \& Rachael H. Carrie
}

\begin{abstract}
A new species of Potamocoridae, Potamocoris isbiru, is described from Belize. This taxon is easily recognized by the thick fringes of gold setae on the lateral margins of the head, pronotum and basal hemelytra. This new species also exhibits both fully macropterous and coleopteriform wing morphologies, thereby encompassing the character states previously used to discriminate the genus Potamocoris Hungerford from the genus Coleopterocoris Hungerford. On the basis of this intraspecific wing polymorphism, we conclude that Coleopterocoris is merely the coleopteriform morph of Potamocoris, and synonymize it under the latter genus. Figures of key morphological characters are provided for $P$. isbiru, accompanied by a photograph of typical habitat in which the species occurs, and a distribution map.

Dan A. Polhemus*, Department of Natural Sciences, Bishop Museum, 1525 Bernice Street, Honolulu, HI 96817, USA. bugman@bishopmuseum.org

Rachael H. Carrie, Lancaster Environment Centre, Lancaster University, Lancashire, LA1 4YQ, United Kingdom
\end{abstract}

\section{Introduction}

The family Potamocoridae is confined to the Neotropical Region, with its greatest species richness in South America, and limited representation north of the Isthmus of Panama (Van Doesburg 1984, Longo et al. 2005, Herrera \& Springer 2012). Although Potamocoris beckeri La Rivers is a rather widespread taxon that has been reported from Costa Rica, Honduras, Guatemala and Mexico, the genus Coleopterocoris Hungerford has only been reported in Mesoamerica from Costa Rica (Herrera \& Springer 2012). We now describe a distinctive new species of Potamocoris Hungerford from Belize, and note the occurrence of Potamocoris beckeri in the country as well. In addition, we discuss the remarkable degree of intraspecific wing polymorphism exhibited by our new species, and its implications for genus concepts within the Potamocoridae.

\section{Materials and methods}

All measurements in the descriptions below are given in millimeters, and were made using an Wild M3Z dissecting microscope equipped with an ocular micrometer. Descriptions of color and setiferation were taken from dry pinned specimens.

The following abbreviations are used for specimen depositories:

USNM United States National Museum, Smithsonian Institution, Washington, DC, USA

EMEC Essig Museum of Entomology, University of California, Berkeley, CA, USA

FBAC Freshwater Biological Association, Cumbria, United Kingdom 


\section{Taxonomy}

Potamocoris Hungerford

Potamocoris Hungerford, 1941: 1.

Coleopterocoris Hungerford, 1942: 135 (new synonymy)

\section{Potamocoris isbiru sp. $\mathrm{n}$.}

Figs 1-9

Type material. Holotype, coleopteriod male: Belize, Toledo District, Sapote Creek, MR5, 11 May 2010, MR6, 8 December 2010, amid cobbles, 16Q0327515, 1839758, R. Carrie (USNM). Paratypes, Belize: 1 coleopteroid male, Cayo District, $7.2 \mathrm{~km} \mathrm{~S}$. of Augustine, un-named stream, $8 \mathrm{Au}-$ gust 1993, W.D. Shepard (EMEC, to be deposited in USNM); 1 macropterous female, Toledo District, un-named tributary of Snake Creek, MR10, 18 October 2011, riffle, 16Q0283939 1821744, A. Makin and $\mathrm{O}$. Cal (FBAC). Additional material examined, Belize: 1 immature, same data as holotype (FBAC).

\section{Description of coleopteroid male}

Size. Of moderate size for genus, general body form ovate (Fig. 1). Male length $2.80 \mathrm{~mm}$; maximum width (across central portion of hemelytra) $1.75 \mathrm{~mm}$.

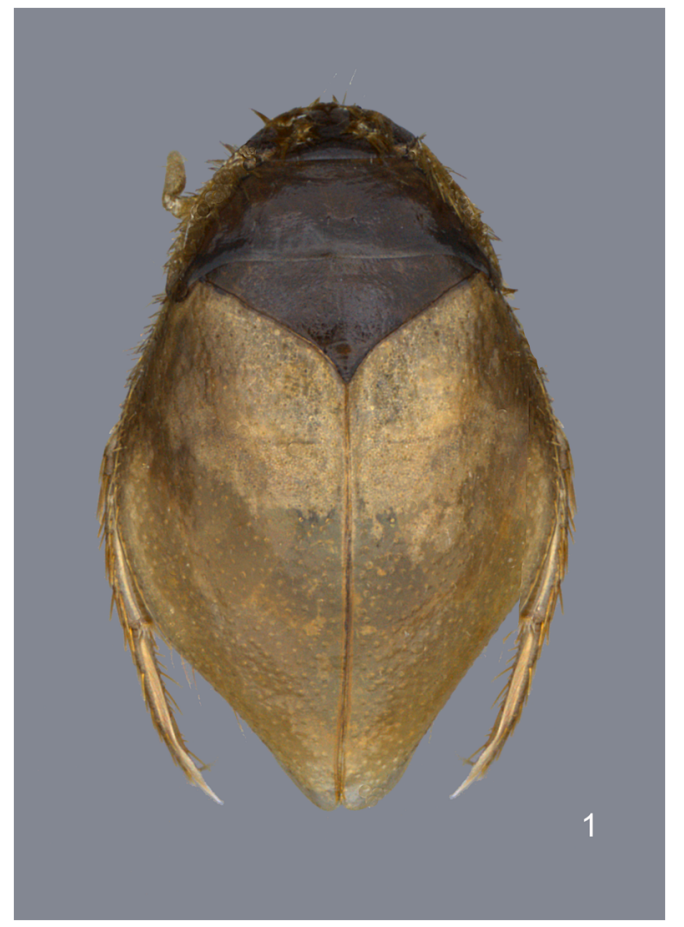

Fig. 1. Potamocoris isbiru n. sp., brachypterous male, dorsal habitus photo (paratype specimen from $7.2 \mathrm{~km}$ S. of Augustine).
Color. Overall coloration dark brown with coleopteriform hemelytra yellowish brown. Head dark brown, shining; eyes dark red, shining; labrum golden; rostrum with all segments golden brown; pronotum dark brown, shining; scutellum dark brown; hemelytra yellowish-brown; ventral surface dark brown; legs brown.

Structural characters. Head width across eyes/ length $=0.60 / 0.50$, bearing numerous long, thickened, gold setae along anterior margin of anteclypeus and in furrows adjacent to inner margins of eyes; eyes roughly teardrop-shaped when viewed from above with weakly developed lateral flange, tapering anteriorly, eye width/length $=0.10 / 0.20$, slightly divergent anteriorly, inner margins separated from vertex by shallow furrows, anterior/posterior interocular width $=0.45 / 0 / 40$; head slightly produced behind eyes, posterior margin of vertex broadly and gently curved; anteclypeus broadly rounded, projecting well ahead of eyes, anterior margin not projecting beyond rostrum, lacking pits or other sensory structures; labrum roughly trapezoidal, ventral margin very broadly rounded; rostrum length 0.45 , reaching beyond fore coxae to posterior margin of prosternum, evenly tapering to apex; antennae long, all segments slender, extending well beyond lateral margins of head, apex of segment IV projecting slightly beyond lateral margin of pronotum, segment I shortest, segments II-IV subequal, lengths of segments II$\mathrm{IV}=0.05,0.10,0.10,0.10$.

Pronotum lacking punctations or rugosity, lateral margins bearing numerous long, thickened, gold setae, width/length (midline) $=1.30 / 0.40$, posterolateral angles broadly rounded, extending backward beyond base of scutellum and overlapping bases of hemelytra. Scutellum weakly rugulose, anterior margin narrowly transversely depressed, width/length (midline $)=1.10 / 0.45$, basal and lateral margins very broadly and weakly sinuate, posterior apex acute. Hemelytra coleopteriform (Fig. 1), extending posteriorly beyond posterior apex of abdomen, costal margins bowed broadly outward and then converging posteriorly to acutely rounded posterior apices, corium and clavus not delineated, wing membrane and all indication of venation absent; hemelytral surface shallowly and coarsely punctate, basal sections of costal margins bearing numerous long, thickened, gold setae; posterior halves of costal margins bearing scattered long golden setae. Abdomen with lateral portions of paratergites not exposed beyond lateral wing margins when viewed dorsally.

Ventral surface bearing scattered long, slender, golden setae; propleura not reflexed posteriorly, not covering basolateral portions of mesosternal plate, anterolateral angles lacking hydrostatic sense organs; prosternal plate sharply raised along longitudinal 

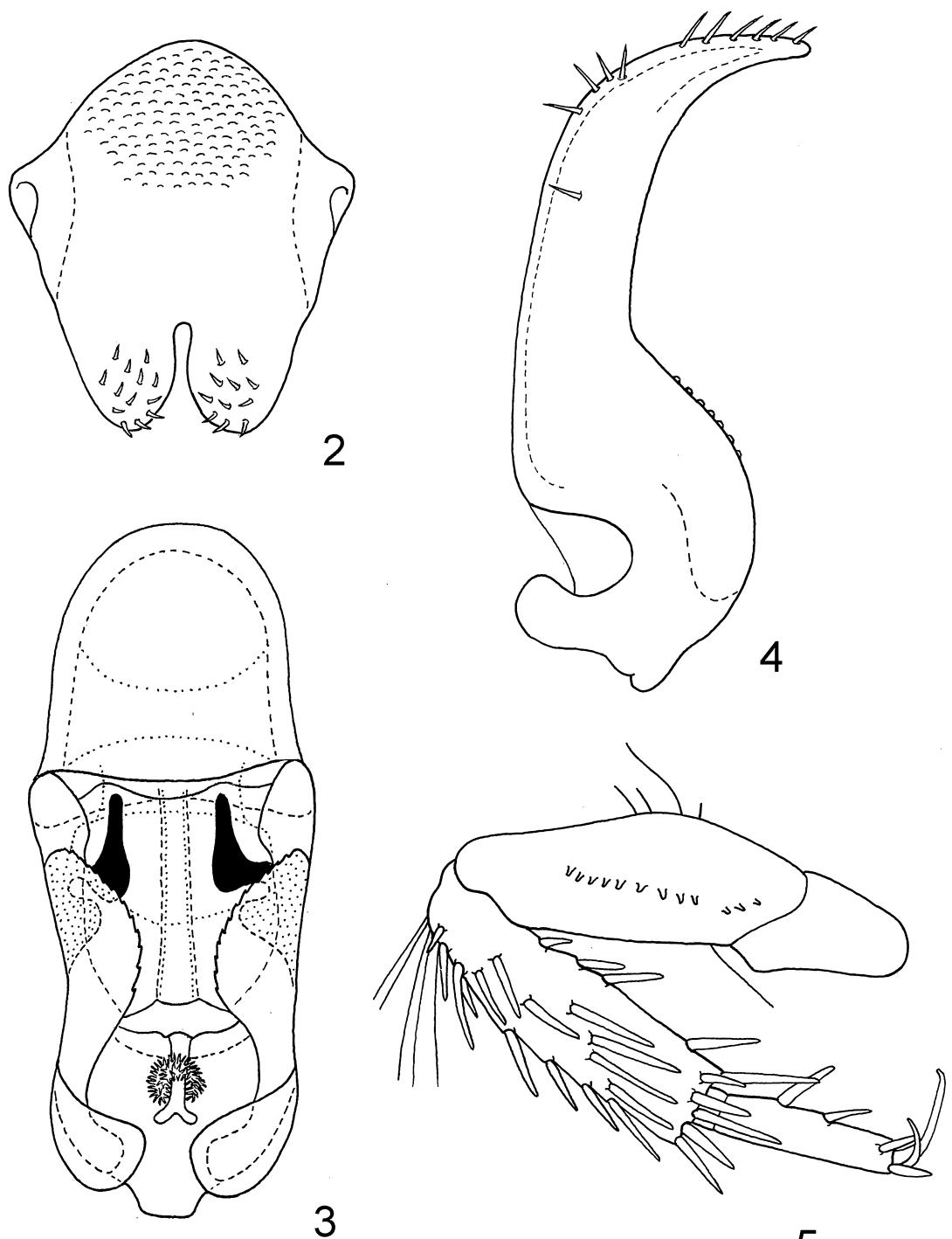

3

5

Figs 2-5. Potamocoris isbiru n. sp., brachypterous male, structural details (holotype specimen from Sapote Creek). 2. Pygophore. 3. Phallotheca and proctiger. 4. Left paramere. 5. Left middle leg, ventral view.

midline to form a narrow carina; mesopleurae and mesosternal plate flat, posterior apex of mesosternal plate acute; metasternal plate small, slightly raised along longitudinal midline, posterior apex acute. Abdominal sternites and parasternites delineated by distinct sutures, lacking evident spiracular modifications or hydrostatic sense organs; posterior margin of abdominal sternite $\mathrm{V}$ bearing 6 small, peg-like setae medially; abdominal sternite VI bearing a deep, $\mathrm{V}$-shaped incision to accomodate genital capsule.

Legs with anterior femur only slightly expanded, anterior and posterior margins both gently our- wardly convex, anterior margin bearing a row of evenly spaced short, straight, stout, peg-like golden setae, posterior margin bearing a fringe of long, slender gold setae; anterior tibia straight, constricted on basal third, posterior margin bearing a row of evenly spaced short, straight, stout, peg-like golden setae; fore tarsi 1-segmented, short and stout, ventral tarsal surface bearing scattered very short, straight, stout, peg-like golden setae, apex of fore tarsus with 2 slender, independently articulated claws of equal size; middle femur moderately swollen (Fig. 5), bearing a few curving, slender gold setae 


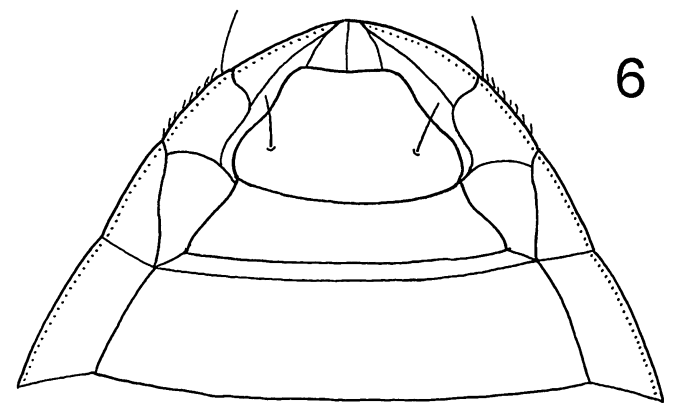

Fig. 6. Potamocoris isbiru n. sp., macropterous female, subgenital plate (paratype specimen from tributary of Snake Creek).

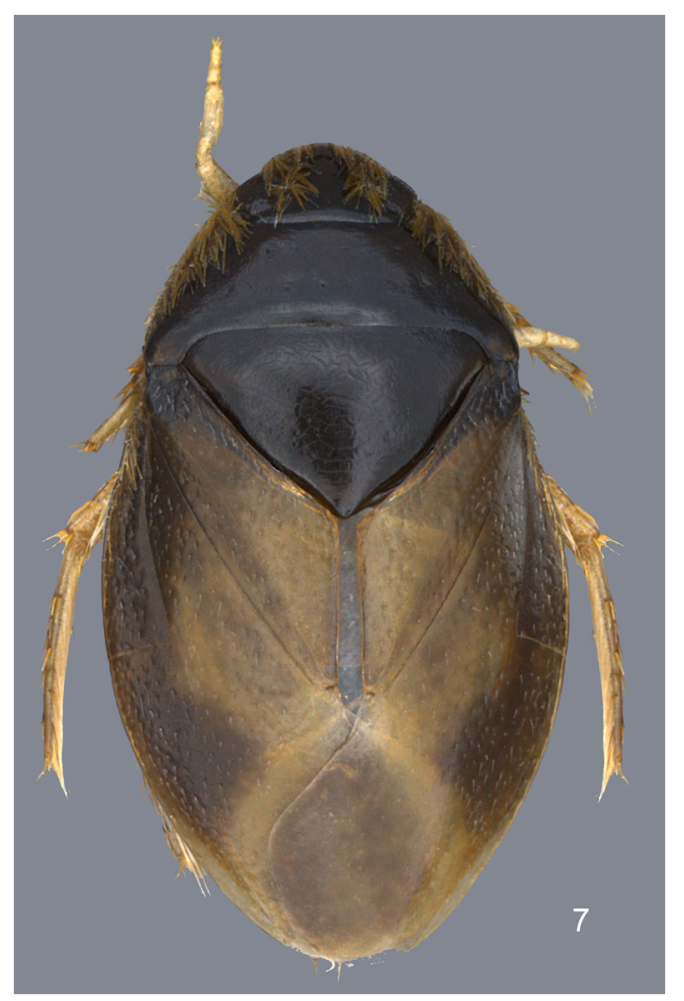

Fig. 7. Potamocoris isbiru n. sp., macropterous female, dorsal habitus photo (paratype specimen from tributary of Snake Creek).

at apex, middle tibia short and stout, bearing numerous long, stout, distally-directed reddish-brown spines (Fig. 5), middle tarsi 2-segmented, basal segment very short, distal segment elongate, bearing a few long, stout, reddish-brown spines, apex with two long, slender claws (Fig. 5); hind femur moderately swollen, bearing a few short, curving golden setae at apex, hind tibia slender, hind tarsi 2- segmented, tibia and tarsi bearing scattered long, stout, golden-brown spines, posterior margins of distal half of tibia and both tarsi with plumes of long, golden swimming hairs, apex of distal tarsus bearing 2 slender claws; measurements of legs as follows: fore femur/tibia/tarsal $\mathrm{I}=0.45 / 0.20 / 0.15$; middle femur/tibia/tarsal $\mathrm{I}=0.50 / 0.45 / 0.25$; hind femur/tibia/tarsal I/tarsal II $=0.75 / 0.70 / 0.45 / 0.30$.

Male genitalia with parameres symmetrical, paramere shape elongate, slender, curving distally, apex acute (Fig. 4); pygophore symmetrical, with posterior section medially incised (Fig. 2); proctiger symmetrical, broadly rounded (Fig. 3); phallotheca symmetrical, internal sclerotization as in Fig. 3.

\section{Description of macropterous female}

Similar to coleopteroid male in general structure, with following exceptions: Larger in overall size, body length 3.20, maximum width (across central portion of hemelytra) 1.75; pronotum dark brown, length 0.30 , width 1.40 ; scutellum enlarged, prominent, dark brown, length 0.75 , width 1.50 , posterior margin angulate but not acuminate; hemelytra complete, reaching to posterior tip of abdomen, with clavus, corium and embolium well defined, membrane lacking evident venation, clavus and corium bearing scattered shallow punctations, embolium rugulose; ventral surface brown, subgenital plate broadly trapezoidal (Fig. 6).

\section{Etymology}

The name "isbiru" (a noun in apposition) refers to the Q'eqchi' Mayan word for "hairy" reflecting the thick fringes of setae on the margins of the head and pronotum in this species. The use of the Mayan word honours the staff of the Ya'axché Conservation Trust, particularly the Maya rangers who collected or assisted in the collection of three of our four specimens.

\section{Distribution}

Belize, Monkey River and Macal River catchments (Fig. 9).

\section{Comparative notes}

Potamocoris isbiru is easily recognized among the Mesoamerican assemblage of Potamocoridae by the dense fringes of gold setae which occur on the head, lateral pronotum, and hemelytral embolium (Figs 1, $8)$. We have examined specimens of three out of the five described species of Potamocoris $-P$. beckeri La Rivers, $P$. parvus Hungerford, and $P$. robustus La Rivers - and find that their pattern of setiferation on the head and pronotum differs greatly from $P$. isbiru. Individuals of $P$. beckeri from Mexico have numer- 


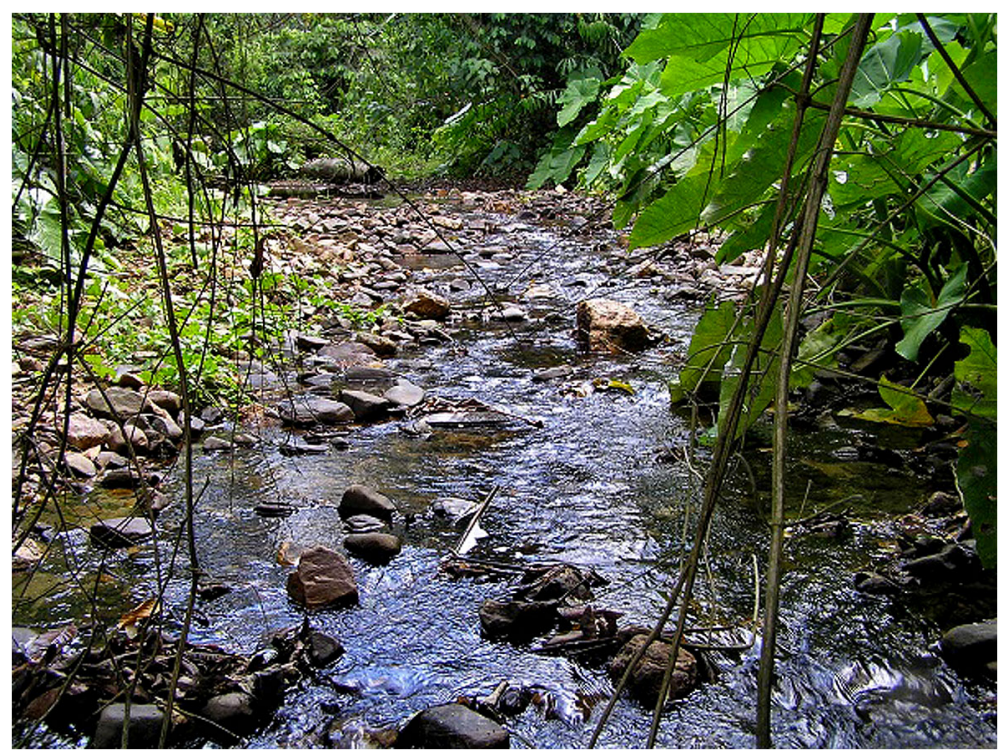

Fig. 8. Photo of Sapote Creek collection locality for Potamocoris isbiru n. sp.

ous, pale, posteriorly recumbent setae on the pronotum and head vertex, as well as a few short, stiff, erect setae on the anterolateral margins of the head in front of the eyes (2-3 on each side); these setae seem to be easily rubbed off, judging by their variable representation in the specimens at hand. Potamocoris parvus specimens from Paraguay have a similar pattern of setiferation, but with the recumbent setae on the pronotum and vertex somewhat less dense. By contrast, specimens of $P$. robustus from Peru have the pronotum and vertex glabrous and lacking recumbent setae, but possess more numerous and longer erect stiff setae on the anterolateral head margins (45 on each side). We have not examined the single female holotype of $P$. nieseri, but Fig. 3 in van Doesburg (1984) indicates that this species has a pattern of pronotal and cephalic setiferation similar to that of $P$. parvus. In no case do any of these species possess the dense tufts of setae laterally on the head and pronotum seen in $P$. isbiru.

We have also examined specimens of three out of the five species originally described in Coleopterocoris - C. plaumanni De Carlo, C. kleerekoperi Hungerford, and C. usingeri De Carlo (see Appendix 1) - and find that their pattern of setiferation on the head and pronotum differs greatly from $P$. isbiru. All of the above Coleopterocoris species possess scattered, short, stiff, erect setae on the lateral margins of the head and pronotum. Although we have not been able to examine a specimen of $C$. hungerfordi, this species by contrast possesses numerous dense setae on the margins of the head and prono- tum, and to judge by Fig. 1 in De Carlo (1968) this pattern of dense setiferation appears to be similar to the character state exhibited by $P$. isbiru. However, other aspects of overall morphology, including the structure of the scutellum, vary markedly between the two taxa (compare Fig. 1 herein to Fig. 9 in Longo et al. 2005).

The male genitalic structures of $P$. isbiru (Figs 24) further serve to distinguish this taxon from other congenors. As is typical of the Potamocorinae, the male genitalia are symmetrical in all respects. As in the Naucoridae the parameres and phallotheca have been inverted front-to-back, such that the articulation points at the bases of the parameres lie posterior to the parameres themselves. Unlike the situation in the Naucoridae, however, the proctiger lies posterior to the parameres, and beneath them, rather than lying anterior to and above the parameres, and articulating upward and out of the way when they are everted, as is the case in the Naucoridae. The structure which we have interpreted as the pygophore possesses a medial slit (Fig. 2), which apparently allows the phallotheca to evert more effectively during mating. A dissection of the male genitalia of Potamocoris robustus from Peru indicates the presence of paired spermathecae, and it is likely these are present in the Belize species as well, although it was not possible to unequivocally confirm their presence, in part because the symmetrical phallothecal sclerotization in $P$. isbiru is far more prominent that in P. robustus.

The paramere of our new Belize species is distinct from any previously illustrated for Coleoptero- 


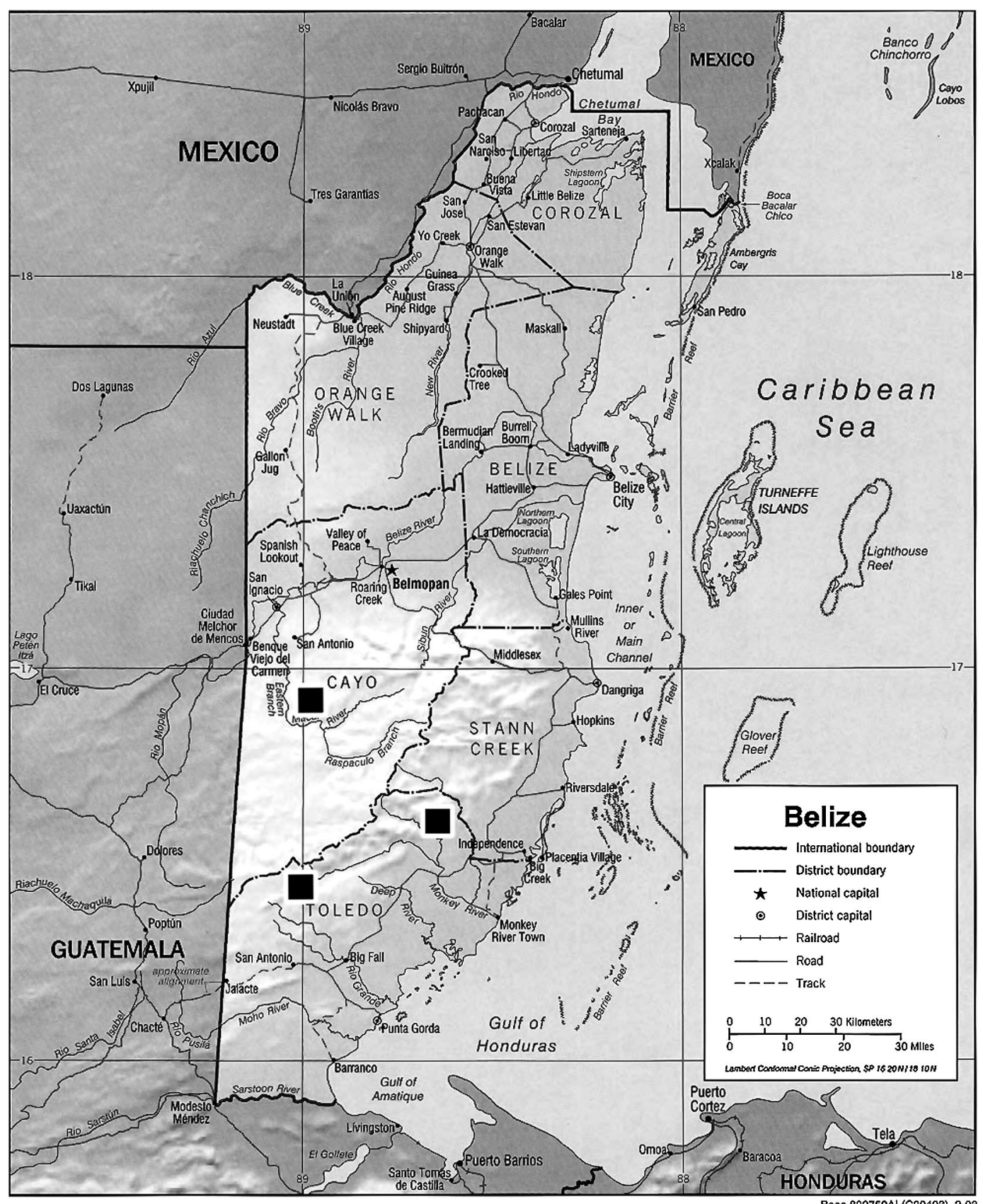

Fig. 9. Map of Belize showing currently known distribution of Potamocoris isbiru n. sp.

coris and Potamocoris in that it is sharply curved on the distal quarter, whereas in the other species the paramere is curved basally and then formed into a long, straight distal blade (compare Fig. 4 herein to Fig. 8 in Hungerford, 1941 and Fig. 6 in Hungerford, 1942). Potamocoris isbiru also lacks prominent basal setae, which are present on the paramere of P. robustus. Small asperities are present on the basal margin of each paramere in P. isbiru (Fig. 4), and would appear to be positioned such that they can potentially contact the rachet-like serrations on the paired sclerites of the phallotheca (Fig. 3), and as 
such may represent a stridulatory mechanism in the genitalia.

In addition, $P$. isbiru is the first known species in the Potamocorinae in which both macropterous and coleopteriform brachypterous morphs are demonstrably present in the same taxon. The family Potamocoridae is currently considered to contain two genera, Potamocoris and Coleopterocoris. These genera have been largely separated to date on the basis of their wing development, with all species of Potamocoris being fully winged, whereas all species of Coleopterocoris have coleopteriform, punctate hemelytra with no indication of a clavus, corium, or forewing membrane, and only partial development of the hind wing. Potamocoris isbiru thus presents a mixture of character states seen in both known genera of Potamocoridae, with the female at hand falling broadly within Potamocoris due to its macropterous form, but possessing dense setiferation on the head and pronotum identical to that seen in our male specimens that would, on the basis of their brachypterous form, be assigned to Coleopterocoris. This combination of morphotypes in a single taxon suggests that in fact the two putative genera currently recognized in the Potamocorinae are simply differing wing morphs which can co-occur on occasion within a single taxon, as is the case in P. isbiru.

\section{Ecological notes}

Potamocoris isbiru appears to be of very localized occurrence within Belize, and to occur at low densities. Three of our four specimens of $P$. isbiru were collected in the Toledo District during surveys for a wider study that aims to facilitate stream bioassessment in Belize. Two were taken by the second author from two separate locations in May and December 2010, on a $3^{\text {rd }}$ order lowland tributary (the Sapote Creek: Long. -88.604495 Lat. 16.631289) of the Swasey Branch of the Monkey River system, in the south of Belize. The Creek arises in the Maya Mountains at approximately 500 m.s.l. and drains primarily Santa Rosa Group geology for $9 \mathrm{~km}$. The Sapote Creek at the type localities was a clear, shallow (mean $10 \mathrm{~cm}$ ), small $(7.5-8.0 \mathrm{~m})$, sand dominated stream of slow to moderate discharge $(0.1-$ $0.2 \mathrm{~m}^{3} \mathrm{~s}^{-1}$ ), with numerous small faster flowing gravel and cobble riffles (Fig. 8).

The upstream Sapote Creek catchment drains part of the western basin of the Cockscomb Basin Wildlife Sanctuary and the Maya Mountain Forest Reserve which, with a history of selective logging and hurricane damage, consist of old growth and young broad-leaf tropical forest. Selective harvesting continues in the catchment immediately upstream of the type localities, but it is otherwise considered mini- mally disturbed. The type series were taken at elevations slightly less than $100 \mathrm{~m}$ from underneath cobbles embedded in sand in shallow, partially shaded riffles of moderate to fast flow $\left(0.13-0.54 \mathrm{~ms}^{-1}\right)$. At the time of collection, water conductivity was low $(<75 \mu \mathrm{s} / \mathrm{cm}), \mathrm{pH}$ circumneutral (mean $=7.3)$ and temperatures warm, ranging from $21.4-25.5^{\circ} \mathrm{C}$.

The third specimen was taken in October 2011 by A. Makin and O. Cal on a $2^{\text {nd }}$ order mid-elevation tributary of the Snake Creek (Long. -89.023756 Lat. 16.467647), an upper reach tributary of the Bladen Branch of the Monkey River system. The tributary arises in the Maya Mountains at approximately 720 m.s.l. and drains the Santa Rosa Group geology for approximately $1.3 \mathrm{~km}$ through the minimally disturbed broad-leaf tropical forest of the Bladen Nature Reserve. The tributary at the type locality was a clear, shallow $(\bar{x}=10 \mathrm{~cm})$, narrow $(\bar{x}=2.6 \mathrm{~m})$, fine gravel $/$ sand and cobble dominated stream of slow discharge $\left(0.04 \mathrm{~m}^{3} \mathrm{~s}^{-1}\right)$. The specimen was taken at 600 m.s.l. where water temperature was $21.9^{\circ} \mathrm{C}$, conductivity low $(<75 \mu \mathrm{s} / \mathrm{cm})$ and of basic $\mathrm{pH}$ (mean = 7.9).

An examination of extensive collections made by Dr. W.D. Shepard in the 1990s, and earlier collections made by Dr. J.T. Polhemus in the 1970s, both very diligent and competent field collectors of aquatic Heteroptera, have produced only one additional example of this taxon, a brachypterous male from the Cayo District. This analysis also resulted in identification of the first Belize record for P. beckeri, noted in Appendix 1. Because other species of Potamocorinae have been taken at light at night, is possible that future light trapping along small streams in the Cayo and Toledo Districts may be the most promising method for obtaining additional specimens of P. isbiru.

\section{Discussion}

When describing the genus Coleopterocoris, Hungerford (1942) separated this genus from the previously described Potamocoris based solely on the coleopteriform condition of the hemelytra. He noted: "This new bug is without doubt a near relative of Potamocoris parvus Hungerford, and I was tempted to describe it as a new Potamocoris species. While specifically distinct we still have a question which we cannot settle, for we know Potamocoris parvus Hungerford from fully winged forms only, and the new species has the flight wings reduced as in species of Plea, and the hemelytra are shield-like and meet in a straight line down the back without claval suture or embolium. The absence of a claval suture and a marked embolium in forms with aborted flight 
wings may not be of generic significance as has been shown for Helotrephes by Esaki and China, and for Neotrephes (Helotrephidae) by Mr. China. Nevertheless, there are considerations that lead me to erect a new genus for this new insect. In the Naucoridae we have the genus Melloiella De Carlo which is separated from Ambrysus Stål by its greatly modified hemelytra, and in the Pleidae which have the hemelytra meeting in a straight line down the back, as in this new form, there is no difference in this character whether the flight wings are aborted or developed. I would therefore expect that in this new form, if the flight wings are developed, the hemelytra will remain the same shape although a clavus may then be apparent."

Our new species from Belize is the first species of Potamocorinae in which both coleopteriform and fully macropterous morphs are known within the same taxon, and counter to Hungerford's hypothesis there is in fact a significant difference in the wing morphology between the two forms. This wing dimorphism is not sexually partitioned within Potamocorinae, given that we have examined a series of Potamocoris robustus containing both macropterous males and females, taken at light in Peru (see Appendix 1). Similarly, we have seen series of both Coleopterocoris plaumanni and $P$. usingeri from Brazil containing both coleopteriod males and females. Based on this, and the fact that no other salient differences have ever been put forth to separate Potamocoris and Coleopterocoris, we conclude that the latter genus is merely the coleopteroid, brachypterous form of the former, and therefore formally synonymize Coleopterocoris under Potamocoris.

\section{Acknowledgements}

The second author wishes to thank the Ya'axché Conservation Trust for enthusiastic support for freshwater monitoring and assessment in Belize. Special thanks are due to Anignazio Makin, Octavio Cal and Abelino Zuniga whose local expertise made these collections possible. Financial support was provided by the Rufford Small Grants Foundation and a Natural Environment Research Council-Economic and Social Research Council grant. The female specimen was provided to the first author through a kind loan from the Freshwater Biological Association collection (FBAC), Cumbria, United Kingdom. Thanks are also due to the Belize Forestry and Fisheries Departments who approved the scientific collection and export permits that enabled this work.

\section{References}

De Carlo, J.A., 1968. Tres especies nuevas del genero Coleopterocoris y una especie nueva del genero Heleocoris (Hemiptera: Naucoridae). - Physis 28(76): 193-197.

Doesburg, P.H. van, 1984. A new species of Potamocoris Hungerford, 1941 from Suriname (Heteroptera: Naucoridae). - Zoologische Mededelingen 59(2): 19-26.

Herrera, F. \& M. Springer, 2012. First record of the family Potamocoridae in Costa Rica and of Coleopterocoris Hungerford, 1942 in Central America. - Zootaxa 3333: 66-68.

Hungerford, H.B., 1941. A remarkable new naucorid water bug (Hemiptera). - Annals of the Entomological Society of America 34(1): 1-4.

Hungerford, H.B., 1942. Coleopterocoris, an interesting new genus of the subfamily Potamocorinae (Naucoridae: Heteroptera). - Annals of the Entomological Society of America 35(2): 135-139.

La Rivers, I., 1950. A new species of the genus Potamocoris from Honduras. - Proceedings of the Entomological Society of Washington 52(6): 301-304.

La Rivers, I., 1969. New naucorid taxa. - Occasional Papers of the Biological Society of Nevada 20: 1-12.

Longo, R. de Sá, J.R.I. Ribiero \& J.L. Nessimian, 2005. A new species of Coleopterocoris Hungerford from Southeastern Brazil, with notes on $C$. hungerfordi De Carlo and C. kleerekoperi Hungerford (Hemiptera: Heteroptera: Potamocoridae). - Zootaxa 1016: 39-47.

Polhemus, J.T. \& D.A. Polhemus, 1982. Notes on Neotropical Naucoridae II: a new species of Ambrysus and review of the genus Potamocoris (Hemiptera). Pan-Pacific Entomologist 58(4): 326-329.

Received: August 14, 2013

Accepted: September 24, 2013

\section{Appendix 1: Material examined in the course of this study}

\section{Genus Potamocoris}

Potamocoris beckeri La Rivers, 1950 - Distribution: Honduras, Guatemala, Mexico, Belize

1 male, BELIZE, Cayo Dist., unnamed stream $35.1 \mathrm{~km} \mathrm{SE}$ of Belmopan, 3 August 1993, W.D. Shepard (JTPC) new country record. 2 males, 3 females, MEXICO, Veracruz, 36 mi. S. of Acayucan, taken at light, 5 July 1971, Clark, Murray, Hart and Schaffner (JTPC).

Potamocoris parvus Hungerford, 1941 - Distribution: Brazil, Paraguay

1 male, 1 female, PARAGUAY, 45 mi. E. of Horqueta, 7 December 1934, A. Schulze (paratypes, JTPC).

Potamocoris robustus La Rivers, 1969 - Distribution: Peru 1 male, 1 female, PERU, Huánuco, valley of Rio Huallaga, $30 \mathrm{~km}$ N. of Tingo Maria, Santa Teresa, $500 \mathrm{~m}$, November 1955, F. Woytkowski (JTPC); 2 males, 9 females, PERU, Loreto, km 3 on Tournavista Road, 34 km W. of Pucallpa, 
$300 \mathrm{~m}$, at light, December 1971, R.T. and J.C. Schuh (JTPC).

\section{Genus Coleopterocoris}

Coleopterocoris kleerekoperi Hungerford, 1942 - Distribution: Brazil

1 male, BRAZIL, near Porto Alegre, brook between lagoons, littoral region, No. 6-24, November 1941, H. Kleerkoper (paratype, JTPC).

Coleopterocoris plaumanni De Carlo, 1968 - Distribution: Brazil

3 males, 3 females, BRAZIL, São Paulo, Bocaiúva, Rio Piurras, 700 m, December 1962, F. Plauymann (JTPC).

Coleopterocoris usingeri De Carlo, 1968 - Distribution: Brazil 2 males, 3 females, BRAZIL, Rio Santa Maria, $280 \mathrm{~m}$, $31^{\circ} 10^{\prime} \mathrm{S}, 54^{\circ} 23^{\prime} \mathrm{W}$, November 1964, F. Plaumann (JTPC).
Appendix 2: Revised checklist of taxa held in the family Potamocoridae

Potamocoris beckeri La Rivers 1950: 301.

Potamocoris hungerfordi (De Carlo) 1968: 194. New combination

Potamocoris isbiru D. Polhemus \& Carrie 2013: 142.

Potamocoris kleerekoperi (Hungerford) 1942: 138. New combination

Potamocoris nelsoni Longo, Ribeiro \& Nessimian 2005: 41. New combination

Potamocoris nieseri Van Doesburg 1984: 19.

Potamocoris parvus Hungerford 1941: 1.

Potamocoris plaumanni (De Carlo) 1968: 193. New combination

Potamocoris robustus La Rivers 1969: 10.

Potamocoris usingeri (De Carlo) 1968: 196. New combination 
